DOI: $10.15290 /$ bsl.2018.12.12

\author{
Teresa Rączka-Jeziorska \\ Instytut Badań Literackich \\ Polska Akademia Nauk \\ e-mail: teresa.raczka@gmail.com \\ ORCID: 0000-0003-4857-9480
}

\title{
Geografia i kolekcja. \\ O inflanckim doświadczeniu Józefa Weyssenhoffa
}

\section{Z wędrówek po Łatgalii}

Rozważań o podróży jest chyba tak samo wiele, jak wędrujących postaci. Mają swoją fabułę, krajobrazy, a nieraz ciągi dalsze. Na przykład pisarz i wydawca, Marek Zagańczyk, łatwo ulega pokusie błądzenia ${ }^{1}$. Zazwyczaj nie odmawia sobie wtedy przyjemności sporządzania zapisów w dzienniku oraz korzystania z mapy. Czy jednak zawsze daje się prowadzić zaklęciu słynnego autora Pasaży? Kłopoty ma na przykład z dotarciem do Inflant. Choć północno-wschodnie rubieże dawnej Rzeczypospolitej, czyli tereny współczesnej Łatgalii na Łotwie, są już teraz właściwie na wyciągnięcie ręki:

Wiele jest miejsc, których nigdy nie odwiedzę. Jedne są za daleko, inne za blisko, po prostu nie po drodze. Są i takie, które znam, choć nigdy w nich nie byłem. Wystarczyły widoki wyniesione z książek, pejzaże złożone z fragmentów wierszy i odrobina wyobraźni. Lubię wymyślone podróże, wyprawy do miejsc dzisiaj już zatartych, odmienionych. Można wędrować bez końca, odchodzić i wracać. Poznawać inny świat, odmienny od własnego życiorysu. [...] Inflanty zawsze wydawały mi się zbyt bajkowe, by marzyć o ich poznaniu. Nie mieściły się w atlasach gęsto poprzecinanych granicami państw. Należały do przeszłości ${ }^{2}$.

1 W. Benjamin, [Flâneur], w: tegoż, Pasaże, przeł. I. Kania, red. R. Tiedemann, Kraków 2005, s. 461. Por. Wokót pasaży Waltera Benjamina, red. P. Śniedziewski, K. Trybuś, M. Wilczyński, Poznań 2009.

2 M. Zagańczyk, Inflanty, w: tegoż, Cyprysy i topole, Warszawa 2012, s. 81. 
Mimo to, udaje się mu stanąć przed dworkiem w Baltynie, pałacem w Liksnie, podejrzeć okolice Krasławia i Dyneburga, a nawet z powodzeniem rozpoznać portrety służby, ciotek i sąsiadów z okolicznych majątków ${ }^{3}$. Takie, dość niezwykłe, możliwości stwarza bowiem uważna lektura wspomnień z dzieciństwa Kazimiery Iłłakowiczówny utrwalona na kartach Trazymeńskiego zająca4. Ich autorka $\mathrm{z}$ finezją przywołuje te wszystkie punkty oraz identyfikuje postacie, gdyż przecież zna je doskonale od podwórka. Jako mała dziewczynka, wychowanka Zofii Buynowej, wzrastała tutaj w otoczeniu familii Plater-Zyberków. W przestrzeni sygnowanej obecnością bohaterki Śmierci pułkownika oraz wielu nietuzinkowych osobowości rozwinęła swoją poetycką wrażliwość. Dlatego, przeglądając pamiętniki słynnego publicysty oraz działacza politycznego, Bolesława Limanowskiego (1835-1935), z pamięci odtwarza historię i wygląd przywoływanych $\mathrm{w}$ nich miejsc. Zagańczyka natomiast podobny zabieg kosztuje już trochę więcej trudu:

W moich inflanckich podróżach pomocne okazały się zdjęcia i opisy polskich rezydencji zebrane przez Romana Aftanazego. Dzięki nim przyglądałem się fasadzie pałacu $\mathrm{w}$ Liksnie, poznawałem jego kolejnych właścicieli, próbując nie zgubić się wśród pokoleń Plater-Zyberków. Na dołączonych mapach wyznaczałem trasy wędrówek Iłłakowiczówny, miejscowości, które odwiedzała, jej ulubione jeziora i pięknie opisywane rzeki ${ }^{5}$.

Wiedzę o szlacheckich posiadłościach w Inflantach Polskich czerpie eseista ze znanego kompendium do dziejów siedzib ziemiańskich na rubieżach dawnej Rzeczypospolitej ${ }^{6}$ autorstwa wrocławskiego historyka i archiwisty, który swoje obserwacje oparł o wieloletnie badania terenowe. Podwaliną tego opracowania, jak tłumaczy Tadeusz Epsztein, była dokumentacja przekazana Aftanazemu od właścicieli majątków lub osób mających z nimi niegdyś jakichś związek, czyli rozmaite inwentarze, plany, odpisy, a także zachowana korespondencja ${ }^{7}$. Wszędobylski redaktor "Zeszytów Literackich" faktycznie nie dotarł do wymarzonej krainy, choć paryski czy włoski flaneryzm przychodził mu zawsze z łatwością; pod tym względem przypomina Zagańczyk

3 Tamże.

4 Por. K. Iłłakowiczówna, Trazymeński zając: księga dygresji, Kraków 1975.

5 M. Zagańczyk, Inflanty, s. 83-84.

6 Zob. R. Aftanazy, Dzieje rezydencji na dawnych kresach Rzeczypospolitej, t. 1-11, wyd. 2, Wroclaw 1991-1997.

7 T. Epsztein, Nieznane fakty z biografii Romana Aftanazego (1914-2004), „Studia z Dziejów Rosji i Europy Środkowo-Wschodniej", 2015, t. 50, z. 2, s. 111. Por. Z. Żygulski, Uwagi o wnętrzach dworów polskich na podstawie dzieła Romana Aftanazego "Materiały do dziejów rezydencji", w: Dwór polski w XIX wieku. Zjawisko historyczne i kulturowe, red. T. Hrankowska, Warszawa 1995, s. 127-137. 
bohatera debiutanckiej powieści Józefa Weyssenhoffa z 1898 roku ${ }^{8}$, któremu przyjemność sprawiają nie tylko nieustanne podróże, ale także zbieranie wiadomości o swych szlacheckich korzeniach. Jak pisze Jan Tomkowski:

Geografia miejsc odwiedzanych przez pana Zygmunta obejmuje cele dość starannie wyselekcjonowane. Snobistycznie nastawiony podróżnik nie dopuszcza działania przypadku - zwykle podróżuje tam, dokąd podróżować wypada. Zdarza się natomiast, że odwiedza miejscowości w zasadzie niegodne uwagi. Czasem w interesach, lecz chyba częściej - dla przeprowadzenia "terenowych" studiów i wnikliwego porównania, które co prawda rewelacji nie przynosi, ale stać się może tematem ożywionej pogawędki w przyszłości ${ }^{9}$.

Podfilipski oczywiście nie zapuszcza się w odległe Inflanty, tym bardziej, że jako salonowy bywalec o nienagannych manierach pogardza zacofaną prowincją. Preferuje blichtr europejskich miast formatu Paryża, Londynu albo Monte Carlo. Czy późniejszy autor Sobola i panny (1911), który dał się porwać urokom rustykalnego krajobrazu ${ }^{10} \mathrm{~W}$ okolicach Dyneburga, jest do niego choć trochę podobny? Więzi pozarodzinne łączące go z Inflantami Polskimi są wprawdzie znacznie słabsze niż te, którymi mogliby się poszczycić dorastający na tych terenach Iłłakowiczówna czy Limanowski. A jednak swoją znakomitą orientacją $\mathrm{w}$ inflanckich realiach oraz znajomością lokalnej topografii zapewne przekonałby do wyprawy na przykład Zagańczyka, któremu zaimponowało dzieło Aftanazego.

\section{"Zadęcie" do archiwów}

Wracajmy atoli do biografii [Weyssenhoffa - dop. T.R.J.]. Na czym to zatrzymaliśmy się? Na tym, że z odziedziczonych Samoklęsk rad się wymykał na szerszy świat, do Paryża, na Riwierę. Wyruszył raz też i w poetycki wojaż do Grecji, z wizytą do antyku. Jeśli nie bumblował za granicą, to i Warszawie umiał się nie nudzić ${ }^{11}$.

Chronologię dalszych i bliższych wycieczek pisarza w większości ustaliła już dość bogata literatura. Sam baron poświęcił im też trochę miejsca

\footnotetext{
8 J. Weyssenhoff, Żywot i myśli Zygmunta Podfilipskiego, Warszawa 1972, s. 24-25.

9 J. Tomkowski, Magiczne miejsca w powieści Józefa Weyssenhoffa "Żywot i myśli Zygmunta Podfilipskiego", w: tegoż, Szkice młodopolskie, Warszawa 2016, s. 148.

10 Por. tamże, s. 151.

11 A. Grzymała-Siedlecki, Nasz baron, w: tegoż, Niepospolici ludzie w dniu swoim powszednim, Kraków 1962, s. 107.
} 
w swoim biogramie przeznaczonym do Kroniki rodu Weyssów-Weyssenhoffów $w^{12}$, gdzie wyznał, że miały one zazwyczaj spontaniczny charakter, a tylko dwie (do Włoch i Grecji śladami antycznych zabytków) przebiegały według jasno określonego planu. Relację z podróży Weyssenhoffa po dawnych Inflantach Polskich, która nie doczekała się do tej pory szerszego omówienia, znamy dzięki Kartom z pamiętnika, publikowanym wpierw na łamach „Wiadomości Literackich" (1932, nr 8) a następnie w opracowaniu Ireny Szypowskiej (1985). Bohatera tych wspomnień na widok podupadłych rodzinnych majętności dopada „historyczny dreszcz"13, który momentalnie weryfikuje jego wszelkie oczekiwania:

Wikary zaprowadził mnie dość ochoczo do zakrystii, gdzie zaraz ujrzałem $\mathrm{w}$ jednym z rogów pokoju szafę bez drzwi - po prostu kilka wielkich trójkątnych półek zapchanych pożółkłą bibułą. Gdym dotknął pierwszego zwoju, szczur przeskoczył mi przez rękę, ażem się wzdrygnął, a gdym dobył fascykuł, okazało się, że na końcu ukrytym w cieniu pocięty był przez szczury. W głębi półek leżał stos grubej papierowej sieczki. Gdy zwróciłem na to uwagę wikarego przyznał obojętnie, że szczury lubią ciąć papier. Pośpiesznie wyciągałem papiery i przeglądałem odkładając na bok te, które miały pieczęcie i lepiej były zachowane. Na przejrzenie dokładne nie było czasu, bo po kwadransie wikary już ziewał i przestępował z nogi na nogę ${ }^{14}$.

Były one podyktowane nie tylko poznawczymi względami, ale przede wszystkim chęcią pozyskania źródeł do odtworzenia dziejów rodu, który z dzisiejszą Łatgalią miał przecież wiele wspólnego, czemu nie mógł zaprzeczyć nawet sam Gustaw Manteuffel (1832-1916) ${ }^{15}$. Zarzucił on jednak Weyssenhoffom plebejskie korzenie i późne otrzymanie przywileju szlacheckiego (z inicjatywy króla Zygmunta Augusta), do czego przychyla się wielu współczesnych badaczy ${ }^{16}$. Aczkolwiek należy dodać, iż Weyssenhoffowie,

12 Por. Kronika rodziny Weyssów-Weyssenhoffów zestawiona podług dokumentów przez Józefa Weyssenhoffa, wydana po śmierci Autora staraniem Waldemara Weyssenhoffa, z kilkoma przypisami w tekście i poprzedzona krótkim zarysem historii Inflant, Wilno 1935, s. 125.

13 W. Benjamin, [Flâneur], s. 461.

14 J. Weyssenhoff, Inflanty Polskie, w: K.M. Górski, Józef Weyssenhoff, Z młodych lat. Listy i wspomnienia, oprac. i wstęp I. Szypowska, Warszawa 1985, s. 379.

15 Por. G. Manteuffel, O starodawnej szlachcie krzyżacko-rycerskiej na kresach inflanckich, Lwów 1910, s. 63.

${ }^{16}$ J. Bardach, Spór o pochodzenie rodu Weyssenhoffów, w: Kultura średniowieczna i staropolska. Prace ofiarowane Aleksandrowi Gieysztorowi w pięćdziesięciolecie pracy naukowej, red. D. Gawinowa, Warszawa 1991, s. 605-614; K. Zajas, Spór genealogiczny Gustawa Manteuffla z Józefem Weyssenhoffem, w: Józef Weyssenhoff i Leon Wyczółkowski, red. M. Gabryś, K. Stępnik, Lublin 2008, s. 57-63. Por. recenzję Kroniki rodziny Weyssów-Weyssenhoffów autorstwa A. Gieysztora, „Miesięcznik Heraldyczny", 1936, R. 15, nr 7-8, s. 125-127. 
których przodkowie z Inflantami Polskimi byli związani od drugiej połowy XVI wieku, przez następne dwa stulecia wrośli w miejscową tkankę społeczną w takim stopniu, że u schyłku Rzeczypospolitej Obojga Narodów nikt nie kwestionował ich szlacheckości. Krytyczne uwagi genealogiczne Manteuffla, jakie odczuł później na własnej skórze Józef Weyssenhoff, odniosły mimo wszystko przeciwny skutek do zamierzonego. Jak słusznie zauważył Krzysztof Zajas, wręcz inspirowały oraz zachęcały pisarza do kompletowania, właściwie przez całe życie, pokaźnego materiału historycznego na temat dziejów swojej rodziny ${ }^{17}$, czego wyrazem była między innymi wspomniana Kronika, w której to Weyssenhoff „pożegnał ginący świat polskiego ziemiaństwa"18. Nic zatem dziwnego, że na drodze ku osiągnięciu tego celu niestraszne mu były ani szczury, zapamiętale trawiące ostatki istniejących dokumentów, ani dojmująca opieszałość miejscowych. Chciał przecież samodzielnie dotrzeć do oddalonych "gniazd rodzinnych"19. Stamtąd pochodził nie tylko jego znamienity i utytułowany pradziad, podkomorzy inflancki Michał Weyssenhoff (1715-1789) ${ }^{20}$, noszący dumnie wstęgę orderu św. Stanisława, ale także większość krewnych. Poza tym do archiwów, a przede wszystkim historycznych artefaktów, jak mawiano w jego dorpackiej Alma Mater, miał niebywałe „zadęcie” ${ }^{21}$. W jednym z artykułów sformułował nawet specjalne zalecenia dla potencjalnych zbieraczy polskich pamiątek, odradzając m.in. zaopatrywanie się u przekupniów w różne bezwartościowe przedmioty np. buty księcia Józefa, rzekomo wydobyte z rzeki Elstery czy też gęsie pióra, pozostałe po Mickiewiczu. Tłumaczył to w następujący sposób:

Przedmiot z epoki dawnej, zarówno jak z doby bieżącej, może mieć $\mathrm{w}$ sobie dużo treści, albo wcale jej nie posiadać. Gromadząc zbiory, trzeba mieć tę wartość przedmiotów ciągle na oku: co one znaczą lub znaczyć mogą dla nauki

\footnotetext{
17 K. Zajas, Spór genealogiczny Gustawa Manteuffla z Józefem Weyssenhoffem, s. 63.

18 Tamże.

19 Kronika rodziny Weyssów-Weyssenhoffów..., s. 125.

20 Tamże, s. 59-62.
}

21 Znaczenie i sposób użycia tego określenia tłumaczy Józef Weyssenhoff w następujący sposób: „Mieliśmy w Dorpacie osobną gwarę polską, której słownika nikt pono nie spisał. Jeżeli przepadnie, będzie mała szkoda dla lingwistyki, bo innowacje polegały głównie na skażeniu mowy przez mnóstwo wyrazów niemieckich lub czuchońskich i na przekręcaniu znaczenia wyrazów polskich. [...] Jedyny wyraz szczęśliwie ukuty, który mi pozostał z gwary dorpackiej, to - zadęcie, oznaczające humor, fantazję, usposobienie do wybryków i awantur. Ale i tego używano czasem niepotrzebnie jako równoważnika wyrazu chęć. «Mam dzisiaj zadęcie do pieczeni cielęcej» albo "zadęcie do nauki» - to niedorzeczne. Co innego «ponosi mnie zadęcie» - to coś dodaje do słownictwa" [Zob. J. Weyssenhoff, Wspomnienie z Dorpatu (1879-1884), w: K. M. Górski, J. Weyssenhoff, Z młodych lat. Listy i wspomnienia, s. 410]. 
i rozkoszy przyszłych pokoleń. Dlatego rozumny zbieracz nabywa nie tylko przedmioty dawne, lecz i współczesne ze swego zakresu. Wystrzega się tylko fałszerstw i naśladownictw ${ }^{22}$.

Mimo swego lekkiego podejścia do świata ${ }^{23}$, był człowiekiem skrupulatnym. Pod koniec życia prowadził na przykład specjalny zeszyt, gdzie po każdych imieninach, przypadających na dzień 19 marca, notował, ile osób złożyło mu życzenia osobiście, ile otrzymał listów, a ile depesz ${ }^{24}$. Swoje zbiory starał się zaś utrzymywać $\mathrm{w}$ jak najlepszym porządku. W samoklęskim dworze przeznaczył dla nich największy pokój mogący pomieścić aż dziewiętnaście szaf z książkami, który co rusz zapełniał nowymi nabytkami ${ }^{25}$ :

Pan Józef niestrudzenie szpera po antykwariatach, wyławiając z manią kolekcjonera ulubione sztychy polskie, wszelkie druki odnoszące się do epoki stanisławowskiej i numizmaty, których zbiór staje się wkrótce doprawdy imponujący ${ }^{26}$.

Zaczątek pokaźnego księgozbioru barona stanowiły woluminy otrzymane notabene $\mathrm{w}$ spadku po krewnych z Inflant Polskich, generale Janie Weyssenhoffie (1774-1848) oraz pośle na Sejm Czteroletni, Józefie Weyssenhoffie (1760-1798). Dziś jednym z namacalnych reliktów tej bogatej kolekcji jest szafa biblioteczna ${ }^{27}$ znajdująca się obecnie w warszawskiej czytelni Instytutu Badań Literackich PAN ${ }^{28}$. W historii literatury zwracano już niejednokrotnie uwagę na bibliofilską pasję oraz archiwistyczne zacięcie „arystokraty z Kresów Wschodnich" ${ }^{29}$, którym zawdzięczamy wiele rzadkich druków i cennych rękopisów, lecz zdecydowanie najpełniejszą charakterystykę tego aspektu

22 J. Weyssenhoff, O „zbieraczu polskim”, „Przewodnik Antykwarski” 1910, nr 1, s. 3.

23 Zofia Starowieyska-Morstinowa wspomina na przykład: „Weyssenhoffem interesowano się może bardziej niż innymi krewnymi, z początku z powodu jego dość hulaszczego życia i różnych tzw. skandali, które wszystkimi bardzo wstrząsały, gdyż mocno odbijały od surowych obyczajów reszty rodziny" [zob. Z. Starowieyska-Morstinowa, Józef Weyssenhoff, w: tejże, Ci, których spotykałam, Warszawa 1993, s. 233].

24 A. Grzymała-Siedlecki, Nasz baron, s. 118.

25 M. Wychowańska, O Józefie Weyssenhoffie bibliofilu i zbieraczu, „Kamena” 1961, nr 9, s. 3.

26 T. Gicgier, Samoklęski, w: tegoż, O człowieku, któremu wystarczał ogarek, Warszawa 1979, s. 213.

27 Na jej szczycie znajduje się kartusz herbowy z wyrzeźbioną w centrum literą „B".

28 Trafiła tam za pośrednictwem prof. Jana Michalskiego (1876-1950), który po I wojnie światowej przejął znaczną część biblioteki pisarza. Więcej na ten temat zob. E. Danowska, Józef Weyssenhoff (1860-1932) - pisarz, bibliofil, kolekcjoner, Kielce 2015, s. 184-185.

29 Tak nazywa go np. Jolanta Chwastyk-Kowalczyk [zob. J. Chwastyk-Kowalczyk, Obszary działalności Józefa Weyssenhoffa - literackie, bibliofilskie, kolekcjonerskie i inne, „Toruńskie Studia Bibliologiczne" 2016, nr 1, s. 241]. 
twórczości pisarza zaprezentowała ostatnio Ewa Danowska. Badaczka przyjrzała się inwentarzom należącym niegdyś do Józefa Weyssenhoffa i przeanalizowała ich losy. Zwróciła ponadto uwagę, że rodowe papiery pisarz kompletował przez prawie czterdzieści lat, a do poszukiwań zaangażował swego młodszego brata Waldemara (późniejszego wydawcę Kroniki), który wraz z nim prowadził kwerendę w bibliotekach i archiwach Rygi, Sztokholmu czy Berlina, robiąc wypisy oraz uwierzytelnione kopie ${ }^{30}$. Rezultatem ich archiwalnych wojaży jest m.in. 746 dokumentów z lat 1574-1916, przechowywanych obecnie w Litewskim Państwowym Archiwum Historycznym w Wilnie ${ }^{31}$. Spora część tego rodzinnego zbioru znajdowała się niegdyś w Samoklęskach, następnie, za pośrednictwem Waldemara Weyssenhoffa została przewieziona do Kijowa, a stamtąd w 1985 roku trafiła na Litwę ${ }^{32}$. Historia niebieskiego zeszytu z rękopiśmiennymi notatkami o podróży po Inflantach $\mathrm{w} 1887 \mathrm{roku}$, odnalezionego $\mathrm{w}$ tej kolekcji, nie została do tej pory bliżej zbadana. Wiadomo jednak na pewno, że należał do Józefa Emanuela Weyssenhoffa.

\section{Miejsce autobiograficzne}

Gdyby nie znajdujące się w rękopisie inicjały oraz charakterystyczny dla pisarza staranny dukt pisma, proweniencja autografu nie byłaby tak oczywista. Praktyka geopoetyki, a przede wszystkim sposoby postrzegania miejsca, które, „ożywia się, daje znaki i wskazówki” (Walter Benjamin), a „całkowicie poznane otwiera się" (Kenneth White) ${ }^{33}$, wzbogacają nas o kolejne narzędzia. Pomocne może się tu okazać wyodrębnienie, za Małgorzatą Czermińską, kategorii tzw. miejsca autobiograficznego, tym bardziej, że spełnione zostały wszelkie niezbędne ku temu warunki. Przeanalizowany wstępnie kontekst biograficzny wskazuje na bezpośredni związek pisarza z określonym terytorium, jakim są niewątpliwie dawne Inflanty Polskie, zaś opublikowana relacja z podróży po łatgalskich ziemiach świadczy o rozwiniętej wyobraźni topograficznej autora ${ }^{34}$. Ponadto, jeśli wgłębimy się w chronologię wydarzeń

\footnotetext{
30 Tamże, s. 167.

31 Tamże, s. 161.

32 Tamże, s. 160-161.

33 W. Benjamin, [Flâneur], s. 461; K. White, Geopoetyki, oprac. i przeł. K. Brakoniecki, Olsztyn 2014, s. 24.

34 Por. M. Czermińska, Miejsca autobiograficzne. Propozycja w ramach geopoetyki, „Teksty Drugie” 2011, nr 5, s. 190.
} 
z życia Józefa Weyssenhoffa, odnajdziemy kilka dat świadczących o jego rzeczywistych kontaktach z tymi terenami. Jak podkreśla Czermińska:

Badając miejsce autobiograficzne, trzeba wziąć pod uwagę szereg różnorodnych sytuacji, składających się na egzystencję pisarza, miejsce urodzenia, miejsce dzieciństwa, lat szkolnych, odbywania studiów, trasy i miejsca widziane w podróży, a także zmiany miejsc zamieszkania ważne z punktu widzenia śladów zostawionych w twórczości ${ }^{35}$.

W 1883 roku, czyli po prawie czterech latach spędzonych na Uniwersytecie w Dorpacie na wydziale prawa, Weyssenhoff osiada w Samoklęskach i zaczyna doglądać swojego majątku ${ }^{36}$. Pielęgnowanie rodzinnej siedziby nie sprawia mu jednak tyle przyjemności, co „nobliwe zajęcia kolekcjonera ${ }^{37}$ oraz miłośnika "starożytności»" 38 . Wczytuje się więc z zapałem w dokumenty rodowe, zaś posiadłość, jak zauważa Irena Szypowska, urządza nie wedle potrzeb agronoma, ale erudyty, konesera i pisarza ${ }^{39} .18$ stycznia 1885 roku pisze w liście do swego kuzyna Konstantego Marii Górskiego, z którym przez wiele lat pozostawał w przyjacielskich stosunkach:

Przed kilku dniami wynalazłem sobie bardzo przyjemne i pouczające towarzystwo w osobie brata mojego dziadka. Czytam Pamiętniki Generała Weyssenhoffa, do których dotąd nie zajrzałem, a które w zapomnianym rękopisie na dnie jednej z szaf bibliotecznych leżały. Pisane nie bardzo czytelnie, bladym atramentem, na niebieskim papierze, dość pośpiesznie, bez literackiego obrobienia - po prostu dla wnuków notatki. Spisane w roku 1838-40, podczas gdy już Generał lat 70 blisko liczył, w niektórych miejscach są poprzerywane lub niedopełnione. Ale ciekawe bardzo z powodu, że wszystkie historyczne postacie od r. 1788 do 1830 przesuwają się w nich po kolei; przy tym mnóstwo osób znajomych o tyle, że są dziadkami naszych znajomych lub krewnych. Jestem zaledwie w pierwszej połowie, nie mogę więc zdania mieć o całości, wrażenie jednak robią takie: jako materiał historyczny podrzędnej wartości, ale jako materiał biograficzny i odbicie charakteru epoki i obyczajów epoki bardzo ciekawe. $\mathrm{W}$ miarę jak postępuję z czytaniem, przepisuję tekst (inaczej trudno komukolwiek je dać do przeczytania, tak są nieczytelne) i robię uwagi na marginesie. Potem zabawię się napisaniem tych pamiętników de noviter w bardziej literackiej formie, z koniecznymi poprawkami (nie zmieniającymi ani rozszerzającymi

35 Tamże, s. 191.

36 Por. I. Szypowska, Weyssenhoff, Warszawa 1976, s. 30.

37 Por. Kolekcjonerzy, zbieracze, kwestarze w literaturze i kulturze XIX $i$ XX wieku, red. J. Lekan-Mrzewka, M. Kulesza, B. K. Obsulewicz, Lublin 2016.

38 Zob. tamże, s. 31.

39 Zob. tamże. 
treści, ale porządkującymi ją nieco) i z moimi notatkami poza linią - jednym słowem, jak do druku je przygotuję - a czy drukować je warto, o to dopiero światłej rady, a naprzód Twojej, zasięgnę. Jeżeli nie, to przynajmniej w tej formie zostaną jako bardzo cenna rodzinna pamiątka ${ }^{40}$.

Wrażenia z lektury wspomnień zaawansowanego wiekiem żołnierza i oddanego sprawie patrioty nie pozostają bez wpływu na dalsze poczynania ich przyszłego wydawcy, zapalonego już na dobre do grzebania w rodzinnych szpargałach. Niedługo po tym Weyssenhoff postanawia więc obejrzeć z bliska miejsce urodzenia uczestnika wojen napoleońskich, a przede wszystkim ojczyste ziemie swoich przodków:

Choć mam o Inflantach Polskich dużo powiadomień dokumentalnych, nie znam dostatecznie samej krainy, do której zajrzałem tylko dwa razy w życiu przed rokiem 1890. [...] Obie moje wycieczki do Inflant przedsięwziąłem głównie dla poznania dawnych rozległych posiadłości mojej rodziny w tamtych stronach ${ }^{41}$.

W opublikowanej w latach 30. XX wieku relacji z podróży do Inflant wyznaje, że dotarł wtedy do siedzib ziemiańskich położonych w Andzelmujży, Rybiniszkach, Dłużniewie, Prezmie, Janopolu, Brodajżu, Sarkaniach oraz zawitał do Rzeżycy i Lucyna. Na inne miejscowości oraz pobliskie majątki „nie starczyło [mu - dop. T.R.J.] czasu wówczas ani później" ${ }^{42}$, do czego także przyznaje się z rozrzewnieniem i nieskrywanym żalem:

Pielgrzymka moja do prochów przodków i do cieni ich siedzib była niedostateczna jako przegląd, choćby powierzchowny, Inflant Polskich. Należało tam zwiedzić przynajmniej górujące dawniej wieżyce świetności tego kraju, jak Prele Borchów, lub kwitnące jeszcze wówczas: Krasław Platerów, Liznę ${ }^{43} \mathrm{Zy}$ berków. [...] Dzisiaj nikt już nie obejrzy tamtych siedzib w stanie choćby przypominającym dawne ich przeznaczenie i wartość historyczną ${ }^{44}$.

Z Kroniki rodziny Weyssów-Weyssenhoffów dowiadujemy się, że pierwsza z polsko-inflanckich wycieczek Józefa Weyssenhoffa miała miejsce jeszcze w 1883 roku, kiedy to pisarz spotkał się w Andzelmujży z jednym ze swoich żyjących krewnych - Michałem Franciszkiem Weyssenhoffem (1829-1889),

\footnotetext{
40 J. Weyssenhoff, Korespondencja Weyssenhoffa z Górskim, w: K. M. Górski, J. Weyssenhoff, Z młodych lat. Listy i wspomnienia, s. 266-267.

41 J. Weyssenhoff, Inflanty Polskie, s. 372, 377.

42 Tamże, s. 380.

43 Zapewne błąd w druku, gdyż chodzi o miejscowość Liksna w dawnych Inflantach Polskich.

44 J. Weyssenhoff, Inflanty Polskie, s. 380.
} 
synem Alfonsa i Róży z Siellawów ${ }^{45}$, który pokazał mu wiele pamiątek rodzinnych, a niektóre dokumenty oraz portrety nawet udostępnił do skopiowania ${ }^{46}$. Druga zapewne odbyła się w 1887 roku, o czym świadczą rękopiśmienne notatki pozostawione właśnie $\mathrm{w}$ niebieskim zeszycie.

Kreacja miejsca autobiograficznego nie opiera się [...] tylko na własnym doświadczeniu egzystencjalnym, ale wiąże się z poznawaniem tradycji miejsca oraz uczestniczeniem $\mathrm{w}$ niej - nawet jeśli związki $\mathrm{z}$ cudzymi świadectwami są ukryte, tylko aluzyjne ${ }^{47}$.

Wprawdzie przecierając na mapie polsko-inflanckie szlaki, Weyssenhoff dysponował już pewną wiedzą na temat swego "prarodzinnego kraju”, jednakże chyba nie do końca zdawał sobie sprawę, że zastane realia zweryfikują jego prywatne sądy ${ }^{48}$. Z niegdyś tętniących życiem pałaców pozostały opuszczone „umarłe" gmachy, a ich wnętrza chyliły się wyraźnie „do upadku”. Niewiele lepsze wrażenie budowali także miejscowi, u których pisarz próbował zasięgnąć języka, tj. wspomniany proboszcz, kobiecina spotkana w jednym z majątków czy "stary, podrujnowany" krewny, Michał Weyssenhoff. I choć jak sam przyznał: "był to przegląd raczej żałobny" ${ }^{49}$, postanowił utrwalić go na papierze. Dziś wiemy, że funkcjonuje on w dwóch przekazach: literackim, zapisanym na kartach cytowanych wspomnień i w postaci luźnych rękopiśmiennych notatek, roboczo zatytułowanych Notatki statystyczno historyczne, familijne $z$ podróży po Inflantach $1887 r^{50}$, które są chyba najbardziej intymnym zapisem jego wrażeń. W notatkach tych pisarz dokonuje przede wszystkim precyzyjnej inwentaryzacji oglądanych miejsc oraz przedmiotów. I co istotne, nie jest ona efektem jakiejś chwilowej zachcianki. Dzięki temu Weyssenhoff realizuje swą wielką dokumentacyjną, a zarazem rodzinną misję. Z namaszczeniem ogląda więc każdą ścianę, kamień czy portret, zaś obecny stan majątku rejestruje $\mathrm{z}$ geometryczną dokładnością, np. podając

\footnotetext{
45 Kronika rodziny Weyssów-Weyssenhoffów..., s. 128-129, 115.

46 Tamże, s. 129.

47 M. Czermińska, Miejsca autobiograficzne, s. 191.
}

48 Jeszcze bardziej przygnębiające odczucia z wizyty w dawnych Inflantach Polskich zanotował kilkadziesiąt lat później ks. Leon Broel-Plater: „Znikły staropolskie dwory i dworki drzewami ocienione, znikły rezydencje, pałace, zamki, ich ogrody i parki, lub jeśli stoją jeszcze, to albo na wpół zburzone, albo odarte z wszystkiego, co stanowiło ich piękno i artystyczną wartość [...]" [zob. Ks. L. Broel-Plater, Krasław, Londyn 1975, s. 5].

49 J. Weyssenhoff, Inflanty Polskie, s. 377.

50 LVIA F. 1505, Ap. 1, B. 56. Zob. edycję źródłową tego rękopisu wraz z komentarzami w książce T. Rączka-Jeziorska, Inflanckie pitoreski. Kultura dworu ziemiańskiego dawnych Inflant Polskich w XIX wieku, Warszawa 2018. 
liczbę okien w zabudowaniach dworskich, odmierzając odległości pomiędzy poszczególnymi punktami $\mathrm{w}$ terenie, a nawet określając rodzaj upraw albo specyfikę gruntów. Zatrzymuje się nie tylko w pałacach, ale odwiedza cmentarze, kościoły, karczmy czy przydrożne kapliczki. Odsłania stare nagrobki, a następnie przepisuje znajdujące się na nich inskrypcje. Nawiązuje także kontakt z mieszkańcami i stara się od nich pozyskać jak najwięcej informacji, przeprowadzając swego rodzaju ankietę, która niekiedy przynosi całkiem pożyteczne rezultaty np. w postaci szczegółowej charakterystyki konkretnej majętności lub folwarku m.in. pod kątem personaliów dawnych oraz obecnych właścicieli. Dla tych obserwacji niebagatelne znaczenie ma dotyk ${ }^{51}$. Dzięki niemu udaje mu się oszacować nie tylko przybliżony wiek danego przedmiotu, materiał, z jakiego został wykonany, ale także ocenić jego wartość artystyczną. Bez względu na to, czy trzyma w ręku cenną rodzinną pamiątkę, czy pokruszone odłamki kafli, każdy taki artefakt traktuje czule i zmysłowo, gdyż stanowi on duchową spuściznę rodu. I mimo, że Weyssenhoff nie jest z wykształcenia historykiem, cierpliwie odpisuje wszystkie zachowane dokumenty. A trzeba przyznać, że podczas wyprawy do Inflant w 1887 roku odnalazł ich całkiem sporo. Swej kolekcji nie powstydziłby się przed niejednym zawodowym archiwistą i historykiem. Zbiór notatek Weyssenhoffa zawiera niezwykle cenne z perspektywy dzisiejszych badań nad przeszłością Inflant Polskich materiały, przechowywane wówczas przede wszystkim w przykościelnych archiwach w Prezmie, Lucynie i Brodajżu. Są to wypisy z dziewiętnastowiecznych dokumentów o charakterze gospodarczym, z wizytacji kościelnych, kopie wypisów z akt grodzkich dyneburskich z końca XVII i XVIII wieku (tym cenniejsze, że najstarsza partia tych akt, z ostatniej ćwierci XVII stulecia, zaginęła), a nawet kopia przywileju z 1513 roku, dotyczącego Andzelmujży (w tłumaczeniu na język polski z połowy XVIII wieku). Weyssenhoff dokonywał wyciągów z tych materiałów, rzadziej kopiował je w całości, koncentrując się przede wszystkim na informacjach dotyczących przeszłości jego rodziny, ewentualnie miejsc związanych z jego przodkami. Warto dodać, że prócz tego Weyssenhoff doskonale realizuje się również w roli kartografa, o czym świadczy nie tylko jego doskonałe rozeznanie $\mathrm{w}$ lokalnej topografii, ale również odręcznie rysowany plan okolic Małty i Rybiniszek, gdzie czerwoną kredką oznaczona została wcale "nie mała”, droga prowadząca z Prezmy przez Małtę do Rybiniszek, być może jeden z prywatnych szlaków pisarza albo inny ważny rodzinny trakt.

51 R. Tańczuk, Kolekcjonowanie jako doświadczenie haptyczne. Refleksje teoretyczne, „Zbiór Wiadomości do Antropologii Muzealnej" 2015, nr 2, s. 9-24. 


\section{"Gorączka" wyliczenia}

Józefa Ignacego Kraszewskiego, który z zapuszczonego strychu kościółka w Szczuczynie zamierzał przejąć „resztki jakiegoś archiwum, pono Scypionów", nie odstręczały ani grasujące w nim myszy ani cuchnąca woń stęchlizny ${ }^{52}$. Pogniłe szpargały spakowane uprzednio $\mathrm{w}$ worki pisarz załadował na wątłą bryczkę i ledwo dotaszczył do domu. Jego dziwacznej ekspedycji, także $\mathrm{z}$ uwagi na koszty transportu, nie poparli nawet życzliwi mu rodzice, a szczególnie ojciec, zmartwiony słabo rokującą pod względem materialnym przyszłością syna. Pozytywnie ocenił ją tylko sąsiad, Władysław Trębicki, który ,już naówczas nad historią literatury i bibliografią pracował":

P. Władysław rozumiał to najlepiej, iż do wewnętrznych dziejów kraju nie ma dokumentu najmniejszej wagi, który by umiejętnie zużytkowany nie dał z siebie czegoś wyciągnąć. Proste nawet regestra gospodarskie, utrzymywane długo i metodycznie, są pewnym materiałem statystycznym. Miałem już przygotowane co ciekawsze rzeczy, którymi pochwalić się mogłem, i pan Władysław winszował mi, żem miał cierpliwość i wytrwanie odgrzebania tych zabytków przeszłości, na zatracenie skazanych ${ }^{53}$.

Na podobne przedsięwzięcie z pewnością nie odważyłby się bohater powieści Żywot i myśli Zygmunta Podfilipskiego Józefa Weyssenhoffa, jak dowiadujemy się z narracji Jacka Ligęzy, choć w wolnych chwilach z prawdziwym upodobaniem grzebie w starych papierach, by wyszukać informacje o swej rodzinie. Nie skusiłyby go nawet cenne rodowe dokumenty. Przede wszystkim nie pojechałby za nimi aż na daleką prowincję. Jak trafnie zauważa Jan Tomkowski,

Podfilpski bowiem prowincji nie lubi i nawet nie pragnie jej ani poznać, ani zrozumieć. [...] Już dworek szlachecki odcięty od świata, zdaniem miłośnika Paryża, w ogóle nie nadaje się do życia! Nie można stąd wysłać błyskawicznej depeszy, nie można zjeść wytwornej potrawy, brakuje aktualnych wiadomości z szerokiego świata, a przede wszystkim nie ma na kogo popatrzeć, nie ma też publiczności gotowej podziwiać wytwornego bywalca salonów ${ }^{54}$.

Czyż autor tej bestesellerowej kreacji nie postępuje przypadkiem zgoła odmiennie? Pragnienie wyszperania rodzinnych archiwaliów gdzieś w odle-

52 Por. D. Siwicka, Kolekcja wobec nikczemności świata, w: Zdziwienia Kraszewskim, red. M. Zielińska, Wrocław 1990, s. 131-138.

53 J. I. Kraszewski, Noce bezsenne, w: Pamiętniki, oprac. W. Danek, Wrocław 1972, s. 346.

54 J. Tomkowski, Magiczne miejsca w powieści Józefa Weyssenhoffa "Żywot i myśli Zygmunta Podfilipskiego", s. 157. 
głych Inflantach tłamsi na moment jego wielkopańską osobowość. Nie przemieszcza się już po tych stronach tak wytwornie jak paryski przechodzień. $\mathrm{Z}$ pokorą zdaje się na łaskę miejscowych, których niewiele obchodzą rodowe pamiątki czy jakieś stare akta. Kiedy w końcu $\mathrm{z}$ nieskrywanym wzruszeniem dotyka ziemi swych przodków, stojąc u progu "cieni ich siedzib", wpada w cykl gospodarskiego obrachunku. W zapiskach Weyssenhoffa drzemie chyba więcej melancholii aniżeli chłodnej kalkulacji. Odpowiada za nią jednak nie tylko „bezduszna” realność łatgalskiego otoczenia, ale także dająca złudzenie "ładu, porządku, obftości albo pełni" ${ }^{55}$ figura enumeracji ${ }^{56}$, której pisarz daje się retorycznie zdominować. W tej, jak podpowiada Marek Bieńczyk, magicznej chwili, „gdy słyszalny się zdaje głos ludzi i dostrzegalna obecność rzeczy, nieskończone zdanie wyliczenia, uciekające wciąż przed siebie, ostatecznie przypomina tylko o sobie samym, mówi tylko własne słowa, za którymi nie ma już, nie ma wciąż nic" 57 .

\section{Archiwum przestrzeni}

Józef Weyssenhoff, którego w historii literatury nie bez powodu nazywa się "ostatnim wajdelotą polskiego ziemiaństwa" 58, zapełniając - może niepostrzeżenie, ukradkiem bądź w pośpiechu - stronice swojego niebieskiego zeszytu, pewnie nie przypuszczał, jaką wagę będą kiedyś miały jego podręczne notatki. Przestrzeń zapamiętana okiem skrupulatnego intendenta i udokumentowana stosem skopiowanych archiwaliów już dawno przybrała inną postać. „Inflanty Polskie nie istnieją" ${ }^{59}$. Zniknął również stamtąd dumny szlachecki uśmiech ${ }^{60}$. Za sprawą Weyssenhoffa mamy jednak w zamian jej "archiwum", co potwierdziłby pewnie sam Walter Benjamin:

Siła gościńca zależy od tego, czy się nim idzie, czy leci nad nim aeroplanem. Podobnie siła tekstu zależy od tego, czy się go czyta, czy przepisuje. Lecący widzi tylko, jak droga przebiega wśród krajobrazu, ona zaś odwija się mu według

55 Zob. A. Nawarecki, Grzebanie w rzeczach Jarosława Iwaszkiewicza, w: tegoż, Parafernalia, Katowice 2014, s. 203.

56 Por. M. Baron-Milian, Wyliczenie/enumeracja, w: Ilustrowany słownik terminów literackich, red. Z. Kadłubek, B. Mytych-Forajter, A. Nawarecki, Gdańsk 2017, s. 514-519.

57 Przywołuję za M. Bieńczyk, Magiczne wyliczanie, w: tegoż, Melancholia. O tych, co nigdy nie odnajda straty, Warszawa 1998, s. 40.

58 Por. K. Z. Szymańska, Józef Weyssenhoff. Ostatni wajdelota polskiego ziemiaństwa, Częstochowa 2001, s. 379-386.

59 K. Zajas, Nieobecna kultura. Przypadek Inflant Polskich, Kraków 2008, s. 9.

60 Por. A. Grzymała-Siedlecki, Nasz baron, s. 116. 
tych samych praw co teren wokół niej. Tylko idący nią doświadcza jej władzy i tego, jak z terenu będącego dla lotnika tylko rozwiniętą płaszczyzną przyzywa na komendę każdym zakrętem dale, widoki, prześwity, prospekty jak dowódca żołnierzy z pozycji frontowych. Tak komenderuje duszą zajmującego się nim tylko tekst przepisywany, gdy tymczasem zwykły czytelnik nigdy nie poznaje nowych widoków swego wnętrza, jakie toruje tekst, to droga przez ciągle gęstniejącą wewnętrzną puszczę: czytelnik bowiem jest posłuszny ruchowi swego ja w swobodnych przestworzach marzenia, przepisujący zaś oddaje ten ruch pod komendę. Dlatego chińskie kopiowanie ksiąg było niezrównaną gwarancją kultury literackiej, a odpis był kluczem do zagadek Chin ${ }^{61}$.

Na zakończenie warto dodać, że autor Pasaży "flanował” po tych samych zakątkach paryskich co, ćwierć wieku wcześniej, z podobną pasją czynił bohater powieści Józefa Weyssenhoffa.

\section{Bibliografia}

\section{Źródła rękopiśmienne:}

LVIA F. 1505, Ap.1, B. 56.

Aftanazy Roman (1991-1997), Dzieje rezydencji na dawnych kresach Rzeczypospolitej, t. 1-11, wyd. 2, Wrocław: Instytut Sztuki PAN.

Bardach Juliusz (1991), Spór o pochodzenie rodu Weyssenhoffów, w: Kultura średniowieczna i staropolska. Prace ofiarowane Aleksandrowi Gieysztorowi w pięćdziesięciolecie pracy naukowej, red. D. Gawinowa, Warszawa: Państwowe Wydawnictwo Naukowe, s. 605-614.

Baron-Milian Marta (2017), Wyliczenie/enumeracja, w: Ilustrowany słownik terminów literackich, red. Z. Kadłubek, B. Mytych-Forajter, A. Nawarecki, Gdańsk: Słowo/ Obraz Terytoria, s. 514-519.

Benjamin Walter (2005), Pasaże, przeł. I. Kania, red. R. Tiedemann, Kraków: Wydawnictwo Literackie.

Benjamin Walter (2011), Ulica jednokierunkowa, przeł. B. Baran, Warszawa: Aletheia.

Bieńczyk Marek (1998), Magiczne wyliczanie, w: tegoż, Melancholia. O tych, co nigdy nie odnajdq straty, Warszawa: Wyd. Sic!

Broel-Plater ks. Leon (1975), Krasław, Londyn.

Chwastyk-Kowalczyk Jolanta (2016), Obszary działalności Józefa Weyssenhoffa - literackie, bibliofilskie, kolekcjonerskie i inne, „Torunskie Studia Bibliologiczne”, nr 1, s. 241-251.

Czermińska Małgorzata (2011), Miejsca autobiograficzne. Propozycja w ramach geopoetyki, „Teksty Drugie”, nr 5, s. 183-200.

61 W. Benjamin, Ulica jednokierunkowa, przeł. B. Baran, Warszawa 2011, s. 34. 
Danowska Ewa (2015), Józef Weyssenhoff (1860-1932) - pisarz, bibliofil, kolekcjoner, Kielce: Wydawnictwo Uniwersytetu Jana Kochanowskiego.

Epsztein Tadeusz (2015), Nieznane fakty z biografii Romana Aftanazego (1914-2004), „Studia z Dziejów Rosji i Europy Środkowo-Wschodniej”, t. 50, z. 2, s. 105-118.

Iłłakowiczówna Kazimiera (1975), Trazymeński zając: księga dygresji, Kraków: Wydawnictwo Literackie.

Gicgier Tadeusz (1979), Samoklęski, w: tegoż, O człowieku, któremu wystarczał ogarek, Warszawa: Iskry, s. 205-221.

Gieysztor Aleksander (1935), rec.: Kroniki rodziny Weyssów-Weyssenhoffów, „Miesięcznik Heraldyczny" 1935, R. 15, nr 7-8, s. 125-127.

Grzymała-Siedlecki Adam (1962), Nasz baron, w: tegoż, Niepospolici ludzie w dniu swoim powszednim, Kraków: Wydawnictwo Literackie, s. 103-123.

Kolekcjonerzy, zbieracze, kwestarze w literaturze i kulturze XIX i XX wieku (2016), red. J. Lekan-Mrzewka, M. Kulesza, B. K. Obsulewicz, Lublin: Wydawnictwo Katolickiego Uniwersytetu Lubelskiego.

Kraszewski Józef Ignacy (1972), Noce bezsenne, w: tegoż, Pamiętniki, oprac. W. Danek, Wrocław: Zakład Narodowy im. Ossolińskich.

Kronika rodziny Weyssów-Weyssenhoffów zestawiona podług dokumentów przez Józefa Weyssenhoffa, wydana po śmierci Autora staraniem Waldemara Weyssenhoffa, z kilkoma przypisami w tekście i poprzedzona krótkim zarysem historii Inflant (1935), Wilno.

Manteuffel Gustaw (1910), O starodawnej szlachcie krzyżacko-rycerskiej na kresach inflanckich, Lwów: Polskie Naukowe Towarzystwo Herladyczne.

Nawarecki Aleksander (2014), Grzebanie w rzeczach Jarosława Iwaszkiewicza, w: tegoż, Parafernalia, Katowice: Wydawnictwo Uniwersytetu Śląskiego.

Siwicka Dorota (1990), Kolekcja wobec nikczemności świata, w: Zdziwienia Kraszewskim, red. M. Zielińska, Wrocław: Zakład Narodowy im. Ossolińskich, s. 131-138.

Starowieyska-Morstinowa Zofia (1993), Józef Weyssenhoff, w tejże: Ci, których spotykałam, Kraków: Znak.

Szymańska Kazimiera Zdzisława (2001), Józef Weyssenhoff. Ostatni wajdelota polskiego ziemiaństwa, Częstochowa, [Wydawnictwo Wyższej Szkoły Pedagogicznej].

Szypowska Irena (1976), Weyssenhoff, Warszawa: Państwowe Wydawnictwo Naukowe.

Tańczuk Renata (2015), Kolekcjonowanie jako doświadczenie haptyczne. Refleksje teoretyczne, „Zbiór Wiadomości do Antropologii Muzealnej”, nr 2, s. 9-28.

Tomkowski Jan (2016), Magiczne miejsca w powieści Józefa Weyssenhoffa «Żywot i myśli Zygmunta Podfilipskiego», w: tegoż, Szkice młodopolskie, Warszawa: Wydawnictwo Instytutu Badań Literackich PAN, s. 147-162.

Weyssenhoff Józef (1985), Inflanty Polskie, w: K.M. Górski, J. Weyssenhoff, Z młodych lat. Listy $i$ wspomnienia, oprac. I. Szypowska, Warszawa: Państwowy Instytut Wydawniczy.

Weyssenhoff Józef (1910), O «zbieraczu polskim», „Przewodnik Antykwarski”, nr 1, s. $1-3$.

Weyssenhoff Józef (1972), Żywot i myśli Zygmunta Podfilipskiego, Warszawa: Czytelnik. White Kenneth (2014), Geopoetyki, oprac. i przeł. K. Brakoniecki, Olsztyn: Centrum Polsko-Francuskie Côtes d'Armor - Warmia i Mazury. 
Wokót pasaży Waltera Benjamina (2009), red. P. Śniedziewski, K. Trybuś, M. Wilczyński, Poznań: Wydawnictwo Naukowe UAM.

Wychowańska Maria (1961), O Józefie Weyssenhoffie bibliofilu i zbieraczu, „Kamena”, nr 9, s. 3.

Zagańczyk Marek (2012), Inflanty, w: tegoż, Cyprysy i topole, Warszawa: Wydawnictwo Zeszyty Literackie.

Zajas Krzysztof (2008), Nieobecna kultura. Przypadek Inflant Polskich, Kraków: Universitas.

Zajas Krzysztof (2008), Spór genealogiczny Gustawa Manteuffla z Józefem Weyssenhoffem, w: Józef Weyssenhoff i Leon Wyczótkowski, red. M. Gabryś, K. Stępnik, Lublin: Wydawnictwo Uniwersytetu Marii Curie-Skłodowskiej, s. 57-63.

Żygulski Zdzisław (1995), Uwagi o wnętrzach dworów polskich na podstawie dzieła Romana Aftanazego "Materiaty do dziejów rezydencji», w: Dwór polski w XIX wieku. Zjawisko historyczne i kulturowe, red. T. Hrankowska, Warszawa: Stowarzyszenie Historyków Sztuki, s. 127-137.

\section{Geography and Collection. Józef Weyssenhoff's Experience of Livonia}

\section{Summary}

The article analyzes the manuscript recovered in Lithuania which is a personal account of Józef Weyssenhoff's trip through Livonia at the end of the nineteenth century. Józef Weyssenhoff (1860-1932), the famous novelist and renowned "bard" of the landed gentry tradition, never recanted his Polish-Livonian roots. Thanks to his collector's efforts we can now enjoy the invaluable documents on the history of the Weyssenhoff family. As his biography suggests Weyssenhoff's travelling back to his homeland was influenced by something more than his intrinsic curiosity and collector's passion. The author of the article investigates the significance of geography and enquires whether by reading these notes we can evaluate the writer's attachment to the autobiographical place and whether the old Polish Livonia is a place of ancestors. Finally, the author identifies the function of emotions and senses in this personal creation and traces these planes of reference in the poetics of the text.

Keywords: geography, Polish Livonia, private notes, authobiographical place, geopoetics 